\title{
Family planning instructor's performance in the toddler family development program
}

\author{
Simon Sumanjoyo Hutagalung ${ }^{1}$, Dedy Hermawan ${ }^{2}$, Amir Husin ${ }^{3}$ \\ ${ }^{1,2}$ Department of Public Administration, University of Lampung, Bandar Lampung, Lampung, Indonesia \\ ${ }^{3}$ Lampung Representatives Office of National Family Planning Coordination Board, Bandar Lampung, Lampung, \\ Indonesia
}

\begin{abstract}
Article Info
Article history:

Received Jan 29, 2021

Revised May 8, 2021

Accepted Jun 18, 2021

Keywords:

Family planning instructors

Health policy

Performance analysis

Toddlers family development

ABSTRACT

Family planning instructors are vital in implementing the toddler family development program considering their function. This article aims: i) Analyze the performance of family planning instructors in the implementation of the toddler family development program/bina keluarga balita $(B K B)$; ii) Analyse the factors supporting and inhibiting the effectiveness of the performance of family planning instructors in the community. This research used quantitative methods through survey instruments with a population of all family planning instructors which implementing toddler family development program. The pandemic situation has made the data collection process carried out by online questionnaires with Google Forms application. In order to obtain the required data, data collection was carried out through a questionnaire with a sample of 84 respondents. Data analysis was performed through descriptive statistical analysis using MS.Excel and SPSS. The data analysis concluded that the performance of family planning instructors in managing the program is in the good category. In the process approach, effectiveness is shown from the fulfillment of these performance variables in the implementation of the program, so that by looking at the categories in the cumulative analysis that are in the good category.
\end{abstract}

This is an open access article under the CC BY-SA license.

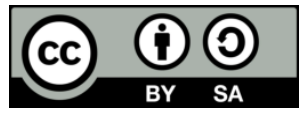

\section{Corresponding Author:}

Simon Sumanjoyo Hutagalung

Department of Public Administration

Universitas Lampung

Jalan Sumantri Brojonegoro No 1 Gedung Meneng, Bandar Lampung, Lampung, Indonesia

Email: simon.sumanjoyo@fisip.unila.ac.id

\section{INTRODUCTION}

In an effort to increase knowledge about the stimulation of children's growth and development at the age of toddlers and during the golden age, parents, especially mothers, must make every effort so that their children's growth and development can be optimal, one of which is by participating in the toddler family development/Bina keluarga balita program which is a program from the Indonesian government (Primary, 2017) [1]. Bina keluarga balita $(B K B)$ is a forum for family activities that have children under five years, the $B K B$ program aims to increase the knowledge and skills of parents and other family members to nurture and foster children's development through physical, mental, intellectual stimulation activities, emotional, spiritual, social, and moral to create quality human resources in order to increase participation, development, and independence of family planning for couples of childbearing age members of the activity group [2]. 
The $B K B$ program is implemented with the following objectives: i). Increasing the knowledge and awareness of mothers and other family members regarding the importance of: -the process of toddler growth in physical, mental and social aspects-Appropriate and integrated services available to children, for example at Posyandu; ii). Improve the skills of mothers and other family members in seeking optimal child growth and development, among others, by using mental stimulation by using educational game tools and utilizing the services available [3]. In its development, this program has adjusted to become an integrative holistic $B K B$ (BKB-HI) where the implementation of $B K B$ services is attached to an integrated service post (Posyandu) and early childhood education programs (PAUD) services [4].

The toddler family development program $(B K B)$ as a part of the family planning program which aims to improve the knowledge and skills of parents and other family members in fostering toddler growth and development through physical, skill, intelligence, emotional and social stimulation [5]. The $B K B$ program is a program from the government in the context of fostering families to realize optimal growth and development of toddlers, and is an effort to provide knowledge and skills to mothers and other family members on how to care for and educate toddlers [6]. At the national level, the existence of $B K B$ groups based on the December 2018 routine report was recorded as 89,015 groups [7].

Realizing the importance and strategy of $B K B$ activities as a way of fostering and preparing human resources quality from an early age in Lampung Province, Indonesia, it is necessary to strive on an ongoing basis for socialization, formation, development and guidance of activity groups in the community [8]. This has spurred the urgency to examine the $B K B$ program, especially in relation to the performance of family planning instructors workers, especially in Lampung Province. Meanwhile, the existence of the family planning instructors as a companion to the $B K B$ program also seems to be dominant in quantity, although there are also conditions of inequality in several region. Distribution of the family planning instructors can be seen in Table 1

Table 1. Distribution of family planning instructors in Lampung province

\begin{tabular}{ccc}
\hline No & Region & Frequency \\
\hline 1 & Lampung Tengah & 70 \\
2 & Pesisir Barat & 12 \\
3 & Lampung Timur & 52 \\
4 & Tulang Bawang Barat & 6 \\
5 & Lampung Barat & 18 \\
6 & Pringsewu & 35 \\
7 & Tulang Bawang & 16 \\
8 & Lampung Utara & 39 \\
9 & Mesuji & 13 \\
10 & Tanggamus & 25 \\
11 & Bandar Lampung & 74 \\
12 & Pesawaran & 30 \\
13 & Metro & 21 \\
15 & Lampung Selatan & 123 \\
16 & Way Kanan & 8 \\
& Total & 542 \\
\hline Source: $B K K B N$ Lampung Province, & 2020
\end{tabular}

Source: $B K K B N$ Lampung Province, 2020

Observing the data above, there are main problems that arise, namely the condition of the family planning instructors distribution which also appears to be uneven in several region where their role is very important for the success of the program. Even so, this condition still has the opportunity to bring out best practices from the role of instructors in the form of action initiatives or consistency they take to produce optimal results compared to other regions. Their performance in intervening with the program's target groups will greatly determine the success of the program in the future.

Meanwhile, it is known that the factors that affect performance are the ability and motivation factors. This is based on the explanation of Davis in Mangkunegara [9] which formulates that: i) Ability factor. Psychologically, abilities consist of potential abilities (IQ) and reality abilities (knowledge+skills). This means that leaders and employees who have an IQ above average (IQ 110-120), especially IQ superior, very superior, gifted and genius with adequate education for their positions and skilled in doing daily work, it will be easier to achieve maximum performance, ii) Motivation factors. Motivation is defined as the attitude of leaders and employees to the work situation in the organization [10]. Those who have a positive attitude towards their work situation will show high work motivation and vice versa. If they are negative to their work situation, it will show low work motivation [11].

Individual performance is the result of employee work both in terms of quality and quantity based on predetermined work standards. This individual performance will be achieved supported by individual 
attributes, work effort and organizational support [9]. In other words, individual performance is the result of i) Individual attributes, which determine the capacity to grind. Individual attributes include individual factors (abilities and skills, background and demographics) and psychological factors include perception, attitude, personality, learning and motivation and ii) Work effort, which forms a desire to achieve something [12].

According to Timple in Mangkunegara [9], performance factors consist of internal factors and external factors. Internal factors, factors associated with a person's characteristics [13]. External factors, namely factors that affect a person's performance that come from the environment. Such as the behavior, attitudes and actions of coworkers, subordinates or leaders, work facilities and organizational climate. These internal and external factors are the types of attributions that employees make have a number of psychological consequences and are based on actions [14]. An employee who considers his good performance comes from internal factors such as ability or effort, it is assumed that this person will experience more positive feelings about his performance than if he attributed his good performance to external factors [15]. The ways an employee describes his own performance also has important implications for how he behaves and acts in the workplace [16].

The factors that influence performance achievement are internal factors and external factors. Internal factors are factors that arise from individuals within the individual, for example work motivation, individual initiative, abilities and knowledge that individuals have to complete organization performance [17]. Meanwhile, external factors are factors that affect the performance that comes from the work environment, for example including the organizational climate and patterns of work relationships among employees within the organization [18].

Performance is used as a basis for appraisal or evaluation and a system which is an important force to influence employee behavior. Performance appraisal aims to motivate employees to achieve organizational goals and to comply with predetermined behavior in order to produce the desired actions and results [19]. Performance is how a person is expected to function and behave in accordance with the tasks assigned to him [20]. Any expectation about how someone should behave in carrying out a task means playing a role. So performance is said to be successful if organizational effectiveness can be realized [21].

Bernardin and Russel in Hendri [22] proposed six primary performances that can be used to measure performance, namely: i) Quality, is the level to which the process or the results of the implementation of activities close to the expected perfection, ii) Quantity, is the amount produced, iii) Timeliness, is the extent to which an activity is completed at the desired time, taking into account other outputs and time available for other people's activities, iv) Cost effectiveness, is the extent to which the use of organizational resources is maximized to achieve the highest yield or reduction of losses from each unit of resource use, v) Need for supervision. Is the extent to which a worker can carry out a job function without requiring the supervision of a supervisor to prevent unwanted actions, and vi) Interpersonal impact it is the degree to which employees maintain self-esteem, good name, and cooperation among colleagues and subordinates [23].

Based on description above, researchers are interested to analyze the performance of family planning instructors and the factors supporting and inhibiting the effectiveness of the performance in the implementation of the toddler family development program $(B K B)$. Therefore, this article aims to: i) Analyzing the performance of family planning instructors in the implementation of the Bina keluarga balita $(B K B)$ program; ii) Analyze the factors supporting and inhibiting the effectiveness of the performance of family planning extension workers in the community.

\section{RESEARCH METHOD}

This research was conducted using a quantitative research design through a survey method, while the instrument used was a questionnaire with a choice of answers and using a Likert scale. This research was conducted using quantitative methods through survey instruments. Test the validity of the instrument in this study using statistical tests and validity tests by expert's judgment where the validators of this research instrument were two Lecturers of Statistics with a background of more than 10 years of experience. Based on the assessment by the expert/validator, the results show that the instrument is valid and can be used for research. In addition, a statistical test of the questionnaire instrument consisting of 25 items was carried out with the $\mathrm{r}$ table value at the $5 \%$ significant level is 0.5484 . The statistical test of the validity of the questionnaire shows that the value of the corected item-total correlation is greater than $r$ table, so it can be said that the instrument is valid. The COVID-19 pandemic situation has made the data collection process carried out to with online closed-question questionnaires on google forms.

The sample in this study was carried out using cluster random sampling because the researcher randomized from a large population [24]. So that the population is selected based on groups, the use of cluster random sampling is also based on efforts to maintain the presence of the sample in each treatment and due to external and internal conditions [25]. Cluster random sampling is a sampling method in which the 
researcher divides the population into several groups based on natural categories or characteristics [26]. To find out the required sample size, the formula is used:

$$
\begin{aligned}
& \mathrm{n}=542 /\left(1+542 \times(0.10)^{2}\right) \\
& \mathrm{n}=84 \text { respondents }
\end{aligned}
$$

So that it is known that the minimum number of respondents needed is 84 people, this number is then used as a reference for determining cluster random sampling based on criteria: i) Demographicgeographic representation and ii) representative of the quantity distribution of the toddler family planning program implementation comunities. Therefore, the sample size still uses 84 respondents the distribution can be seen in Table 2 .

Table 2. Distribution of samples in the study

\begin{tabular}{ccc}
\hline No. & Region & Sample quantity \\
\hline 1 & Lampung Tengah & 10 \\
2 & Bandar Lampung & 20 \\
3 & Lampung Selatan & 39 \\
4 & Pesawaran & 15 \\
& Total & 84 \\
\hline
\end{tabular}

Accordance with the type of research, the quantitative data was analyzed using descriptive statistics using MS.Excel and SPSS. MS.Excel is used in determining the scale and range of scales for measuring performance appraisal categories, while SPSS is used to analyze the obtained questionnaire data. The techniques for determining the scale and range of the scale can be seen in the section below:

Determination of Scale Range (RS) is done with the help of the formula:

$$
\begin{aligned}
& \mathrm{RS}=\mathrm{nx}(\mathrm{N}-1) / \mathrm{N} \\
& \mathrm{RS}=84 \times(4-1) / 4 \\
& \mathrm{RS}=63
\end{aligned}
$$

Then the scale limit is determined as shown in the formula:

MIN Value $=1 \mathrm{x}$, so that MIN Value $=84$

MAX Value: $4 \mathrm{xn}$, so that MAX Value $=336$

Next step is to determine the scale using scale range and scale limit, while the scale used is in the very good to very bad range so that scale value ranges produced as shown in Table 3 . This range of scale values was used to analyze the performance of family planning instructors workers based on the questionnaires that have been filled out previously.

Table 3. Scale distribution and scale range

\begin{tabular}{llllll}
\hline \multicolumn{1}{c}{ Scale } & \multicolumn{3}{c}{ Scale range formulas } & \multicolumn{3}{c}{ Scale value } \\
\hline Very good & MIN + 3RS + 1 & MIN + 4RS & 274 & - & 336 \\
Good & MIN + 2RS + 1 & MIN + 3RS & 211 & - & 273 \\
Not good & MIN + RS + 1 & MIN + 2RS & 148 & - & 210 \\
Not very good & MIN & MIN + RS & 84 & - & 147 \\
\hline
\end{tabular}

\section{RESULTS AND DISCUSSION}

\subsection{Performance analysis of family planning instructors}

These results are presented in the Table 4. The data obtained from the questionnaire is tabulated and then the value of each indicator is calculated and using a scale range that has been prepared beforehand, it can be seen on the Table 4 . 
Table 4. Analysis of family planning instructor's performance on the implementation of $B K B$ program

\begin{tabular}{|c|c|c|c|}
\hline Variable & Indicator & Score & Category \\
\hline \multirow{4}{*}{ Quality } & maintain the quality of the $B K B$ program socialization activities given to the target group & 276 & $\begin{array}{l}\text { Very } \\
\text { good }\end{array}$ \\
\hline & strive for the quality of material and instructors tools that are delivered to the target group & 267 & Good \\
\hline & $\begin{array}{l}\text { resulting in changes in understanding and attitudes of the target group after participating in } \\
\text { the activities carried out }\end{array}$ & 256 & Good \\
\hline & Variable value & 266 & Good \\
\hline \multirow{4}{*}{ Quantity } & $\begin{array}{l}\text { strive to match the number of formal socialization activities and also carry out non-formal } \\
\text { socialization activities }\end{array}$ & 267 & Good \\
\hline & able to prepare a sufficient amount of materials and tools for instructors activities & 241 & Good \\
\hline & $\begin{array}{l}\text { able to seek as much quantity of the target group as possible to participate during program } \\
\text { implementation }\end{array}$ & 258 & Good \\
\hline & Variable value & 255 & Good \\
\hline \multirow{4}{*}{ Timeliness } & $\begin{array}{l}\text { able to maintain the timing of the socialization and program implementation in accordance } \\
\text { with the guidelines }\end{array}$ & 248 & Good \\
\hline & $\begin{array}{l}\text { able to maintain the intensity of the implementation of the counseling in the target group } \\
\text { location }\end{array}$ & 265 & Good \\
\hline & able to strive to align the planned timing of activities with their implementation & 269 & Good \\
\hline & Variable value & 261 & Good \\
\hline \multirow{4}{*}{ Cost effectiveness } & able to plan program activities tailored to the conditions of available resources & 232 & Good \\
\hline & able to seek adequate resources for the implementation of activities in achieving targets & 238 & Good \\
\hline & $\begin{array}{l}\text { able to avoid losses that occur due to inadequate activities or damage to assistive devices in } \\
\text { program implementation }\end{array}$ & 275 & $\begin{array}{l}\text { Very } \\
\text { good }\end{array}$ \\
\hline & Variable value & 248 & Good \\
\hline \multirow{4}{*}{$\begin{array}{l}\text { Need for } \\
\text { supervision }\end{array}$} & willingness to take the initiative to formulate a program implementation plan & 252 & Good \\
\hline & able to carry out activities independently, without waiting for intervention & 223 & Good \\
\hline & requires supervision in the implementation of activities & 272 & Good \\
\hline & Variable Value & 249 & Good \\
\hline \multirow{4}{*}{$\begin{array}{l}\text { Interpersonal } \\
\text { impact }\end{array}$} & the ability to work professionally & 281 & $\begin{array}{l}\text { Very } \\
\text { good }\end{array}$ \\
\hline & maintain ethics and role in work & 259 & Good \\
\hline & ability to maintain coordination with colleagues & 280 & $\begin{array}{l}\text { Very } \\
\text { good }\end{array}$ \\
\hline & Variable value & 273 & Good \\
\hline
\end{tabular}

Source: Research data, 2020

It is worth looking at several indicator points that score very well indicating their superior ability in organizing the $B K B$ program, including professionalism, coordination and teamwork as well as efforts to maintain the quality of the $B K B$ program. This indicates that the family planning instructors' workers have strength in the interpersonal impact and quality of work variables, while the other variables are in the good category even though it indicates that the aspects of confidence are not yet maximal. This means that there may be factors that are still considered constraints in implementing these variables. Later it will be explained in the section of factors that encourage and hinder the performance of family planning instructors' workers in implementing the $B K B$ program. Meanwhile, the cumulative analysis of performance variables can be seen in Table 5 .

Table 5. Cumulative analysis of family planning instructor's performance

\begin{tabular}{llcc}
\hline No. & \multicolumn{1}{c}{ Indicator } & Score & Category \\
\hline 1 & Quality & 266 & Good \\
2 & Quantity & 255 & Good \\
3 & Timeliness & 261 & Good \\
4 & Cost effectiveness & 248 & Good \\
5 & Need for supervision & 249 & Good \\
6 & Interpersonal impact & 273 & Good \\
& Average & 259 & Good \\
\hline Source: & Research data, 2020 &
\end{tabular}

It can be seen that the highest value is owned by the interpersonal impact variable, so it shows that this variable is the strength of the family planning instructors agent in implementing the $B K B$ program, while the smallest variable is the cost effectiveness which indicates if the resources are good budget, strengthening the capacity of human resources is still perceived as a weakness in the implementation of the $B K B$ program. Meanwhile, the cumulative mean value generated from the analysis of the questionnaire is 259 , so that when referring to the scale range table previously described, it means that family planning instructors $(P K B)$ performance in the management of the holistic-integrated $B K B$ program is included in the good category. 
According to Bernardin and Russel in [27] performance is a record of the results obtained from a specific job function or a certain activity during a certain period of time, in this definition Bernardin and Russel emphasize the notion of performance as a result of a job and their contribution to an organization. Meanwhile, according to Byars and Rue in [28] performance is the degree of achievement of tasks completed by employees in their work. Based on the two definitions above, it can be concluded that performance is the work that workers can achieve within a certain period of time in accordance with their duties that lead to an organizational goal. In the process approach, effectiveness is shown by how the performance variables are met in implementing the program. So, it can be said that the performance of the instructors is in good condition, although not very ideal.

\subsection{Analysis of supporting and inhibiting factors for the performance effectiveness of the family planning instructors}

In this section, an analysis of institutional factors is carried out where respondents provide an assessment of the position of these factors in the management of the $B K B$ program in Lampung Province. The results of the questionnaire were then tabulated so that the distribution of the assessment was known in the Table 6.

Table 6. Distribution of factors that encourage or inhibit the $B K B$ program

\begin{tabular}{clc}
\hline No. & \multicolumn{1}{c}{ Category } & Score \\
\hline 1 & Policy instrument are optimal & 23 \\
2 & Policy instrument are adequate but not optimal & 43 \\
3 & Policy instrument still overlapping & 18 \\
4 & Program-related institutions are integrated & 20 \\
5 & Program-related institutions are adequate but not optimal & 48 \\
6 & Program-related institutions are inadequate & 16 \\
7 & The human resources in the program are optimal & 17 \\
8 & The human resources in the program are adequate but not optimal & 40 \\
9 & Human resources in the program do not yet have adequate capabilities & 27 \\
10 & Socio-economic conditions of the community & 20 \\
11 & Environmental safety conditions & 2 \\
12 & Condition of public knowledge and education & 55 \\
13 & Other factors & 7 \\
\hline
\end{tabular}

Source: Research data, 2020

Table 6 shows that the respondents' assessment of this factor is more dominant in the category of community knowledge and education factors with a score of 55, while the category of community socioeconomic conditions is the second most important factor affecting the implementation of the BKB program with a score of 20 and answers to the choice of other factors and environmental safety conditions only has a score of 7 and a score of 2 . For more detail, it is necessary to look at what can be categorized into driving and inhibiting factors in the management of this $B K B$ program, it is can be shown on the Table 7 .

Based on the Table 7, it can be concluded that the supporting factors in implementing this program include: i) Program format that has been designed with a clear vision, mission and objectives as well as a clear program implementation mechanism; ii) Program management that has been tested in the implementation of this type of program; and iii) Efforts have been made to orientate the development of human resource capacity. Meanwhile, in the category of inhibiting factors for program management, it appears to be more of an implementative aspect, including: i) Commitment and policy support between agencies in program management; ii) Coordination between agencies or levels of government in program management; iii) Management of incentive systems for family planning instructors $(P K B)$ and program implementing cadres; and iv) Initiatives and commitment of target communities that need to be more motivated to participate in the program. In the end, it can be concluded that the implementation aspect becomes the background for the emergence of these inhibiting factors, so that it can be said that the $B K B$ program has been well made, but the conditions that occur at the time of implementation make the program face various challenges. The conditions that occur during the implementation of these policies often occur in programs that are broadly prepared and face heterogeneous community conditions [29], so that implementing initiatives are needed to make adjustments within a certain period of time, even though in cross-sectoral aspects such as funding often face obstacles [30]. This challenge that will be faced at the same time must be continuously improved as part of strengthening the capacity of the program in the future. 
Table 7. Identification of supporting and inhibiting factors in the $B K B$ program

\begin{tabular}{|c|c|c|c|}
\hline No. & Factor & Supporters & Inhibitors \\
\hline \multirow[t]{2}{*}{1} & Policy & $\begin{array}{l}\text { The mission of the } B K B \text { program is very clear } \\
\text { and in sync with the PKB's commitments so } \\
\text { far }\end{array}$ & $\begin{array}{l}\text { Consistency in policy support between regions and villages for } \\
\text { the } B K B \text { program }\end{array}$ \\
\hline & & $\begin{array}{l}\text { The program implementation mechanism was } \\
\text { deemed clear }\end{array}$ & $\begin{array}{l}\text { Commitment and attention to the } B K B \text { program by the } \\
\text { regional government and village in the form of budget } \\
\text { support. }\end{array}$ \\
\hline \multirow[t]{2}{*}{2} & Institutional & $\begin{array}{l}\text { The coordination between } \mathrm{BKKBN} \text { and } P K B \\
\text { is felt to be optimal }\end{array}$ & $\begin{array}{l}\text { Coordination of program implementation that has not been } \\
\text { fully supported, especially local and village governments }\end{array}$ \\
\hline & & Program management has been tested & Incentive management for $B K B$ cadres should be strengthened \\
\hline \multirow[t]{2}{*}{3} & $\begin{array}{l}\text { Human } \\
\text { resources }\end{array}$ & $\begin{array}{l}\text { Training and socialization activities were } \\
\text { deemed sufficient for program } \\
\text { implementation }\end{array}$ & $\begin{array}{l}\text { It is felt that the support for providing incentives to PKB } \\
\text { needs to be further strengthened in order to avoid jealousy } \\
\text { with other programs }\end{array}$ \\
\hline & & & $\begin{array}{l}\text { Commitment to maintaining the sustainability of the } \\
\text { instructors }\end{array}$ \\
\hline \multirow[t]{2}{*}{4} & Other factor & & $\begin{array}{l}\text { The condition of public knowledge and education is related to } \\
\text { awareness to maintain initiative and commitment }\end{array}$ \\
\hline & & & $\begin{array}{l}\text { The social and economic conditions of the community, in this } \\
\text { case are related to the ability to participate actively in the } \\
\text { program }\end{array}$ \\
\hline
\end{tabular}

\subsection{Limitation of the study}

The research was carried out in limited mobility so that depth of the specific substance could not be explored more deeply and intimately. The scope of the assessment during the pandemic was colored by the spirit of heroism so that the personal aspect tended to be stronger compared to conditions that did not have many challenges. The sample reach was still limited to some areas so that in future research needs to be considered to further broaden this aspect and be able to make comparisons over time so as to get a complete picture.

\section{CONCLUSION}

Referring to the scale range table previously, it shown that family planning instructors performance is in good category. Meanwhile, supporting factors in the implementation of this program include: i) Program format, ii) Program management, iii) Efforts have been made to orientate the development of human resource capacity. Meanwhile, inhibiting factors on programimplementation, it appears to be more of an implementative aspect, including: i) Commitment and support policy between agencies, ii) Coordination between agencies or levels of government in program management, iii) Management of an incentive system, and iv) Initiatives and commitment of target communities.

The implication from this conclusions is needed a leadership strengthening in order to maintain program commitment and cross-agency coordination to be more optimal. In addition, it is necessary to initiate a reward system that can keep the motivation of family planning instructors in optimal condition. Finally, strong support from the community is also needed to support the implementation of the program, including through socializing the program in various formats and using various media.

\section{ACKNOWLEDGEMENTS}

Thanks to BKKBN of Lampung Province who have supported this research, guidance and useful information in completing this research. We are also grateful to the family planning instructors in Lampung Province, especially as respondents in this research.

\section{REFERENCES}

[1] D. Pratama, "The Impact of Parents' Participation in Family Development Activities of Toddlers on the Stimulation Process of Toddler Development (Study on Family Participants of BKB Flamboyan Rw 03 Cigugur Tengah Subdistrict, Central Cimahi District) (In Indonesia: Dampak Partisipasi Orang Tua Dalam Kegiatan Bina Keluarga Balita Terhadap Proses Stimulasi Tumbuh Kembang Balita (Studi pada Keluarga Peserta BKB Flamboyan Rw 03 Kelurahan Cigugur Tengah Kecamatan Cimahi Tengah)," Jurnal Pendidikan Luar Sekolah, vol. 13, no. 2, pp. 42 52, 2017.

[2] I. Islamiyah, F. B. Awad, and L. Anhusadar, "Outcome Family Development Program for Toddlers (BKB): Parental Counseling in Early Childhood Development (In Indonesia: Outcome Program Bina Keluarga Balita (BKB): Konseling Orang Tua Dalam Tumbuh Kembang Anak Usia Dini, Zawiyah: Jurnal Pemikiran Islam, vol. 6, 
no. 1, pp. 38-55, Jul. 2020, doi: 10.31332/zjpi.v6i1.1797.

[3] F. Wahyuningsih, S. Wahyuni, and E. Widianto, "Implementation of the Bina Keluarga Balita Development Program: Efforts to Strengthen Parents' Ability in Caring for Children (In Indonesia: Kendala-Kendala BKB (Bina Keluarga Balita) Holistik Integratif di Provinsi Sulawesi Utara), Journal of Nonformal Education, vol. 6, no. 2, pp. 176-184, Aug. 2020, doi: 10.15294/jne.v6i2.25185.

[4] U. T. Wijayanti, " Integrative Holistic BKB (Bina Keluarga Balita) Constraints in North Sulawesi Province (In Indonesia: Implementation of the Bina Keluarga Balita Development Program: Efforts to Strengthen Parents' Ability in Caring for Children)," Jurnal Komunikasi, vol. 10, no. 1, pp. 65-76, Jul. 2018, doi: 10.24912/jk.v10i1.205.

[5] H. Wulandari, Y. Supriyati, and F. Jalal, "Evaluation of Holistic Integrative Program in Early Childhood Education and Development (PAUD HI)," International Journal of Multidiscliplinary and Current Research, vol. 6, pp. 406412, 2018, doi: 10.14741/ijmcr/v.6.3.2.

[6] Y. Yasbiati, D. Nugraha, T. Rahman, L. Nur, I. Nurzaman, and A. Tajmiati, "Development of the Integrative Holistic Toddler Family Development Program (BKBHI) to Improve Early Childhood Development in PAUD Kober Ceria (In Indonesia: Pengembangan Program Bina Keluarga Balita Holistik Integratif (BKBHI) Untuk Meningkatkan Tumbuh Kembang Anak Usia Dini di PAUD Kober Ceria)," Prosiding Pengabmas, vol. 1, no. 1, pp. 57-62, Apr. 2018.

[7] BKKBN.go.id, "BKB HI Integrative Holistic Toddler Family Development Program as the Government's Effort to Prevent Stunting (In Indonesia: Program Bina Keluarga Balita Holistik Iintegratif BKB HI Sebagai Upaya Pemerintah Cegah Stunting)," Mar. 15, 2019. [Online]. Available: https://www.bkkbn.go.id/detailpost/programbina-keluarga-balita-holistik-integratif-bkb-hi-upaya-pemerintah-cegah-stunting

[8] A. A. Wulandani, "The Role of Toddler Family Development Cadres in Educating Toddler Parents About Psychosexual Development Stages (In Indonesia: Peranan Kader Bina Keluarga Balita Dalam Mengedukasi Orang tua Balita Tentang Tahapan Perkembangan Psikoseksual)," Jurnal Elektronik Mahasiswa Pend. Luar Sekolah-S1, vol. 7, no. 4, pp. 399-410, Sep. 2018.

[9] A. A. A. P. Mangkunegara, "HR performance evaluation (In Indonesia: Evaluasi kinerja SDM)," Tiga Serangkai, 2005.

[10] A. S. Sutedjo and A. P. Mangkunegara, "The Influence of Competence and Work Motivation on Employee Performance at PT. Inti Kebun Sejahtera (In Indonesia: Pengaruh Kompetensi dan Motivasi Kerja terhadap Kinerja Karyawan di PT. Inti Kebun Sejahtera)," BISMA (Business and Management), vol. 5, no. 2, pp. 120-129, Jun. 2018, doi: 10.26740/bisma.v5n2.p120-129.

[11] A. P. M. dan A. Waris, "Effect of Training, Competence and Discipline on Employee Performance in Company (Case Study in PT. Asuransi Bangun Askrida)," Procedia - Social and Behavioral Sciences, vol. 211, pp. 124001251, Nov. 2015, doi: 10.1016/j.sbspro.2015.11.165.

[12] L. M. D. Menezes and C. Kelliher, "Flexible Working, Individual Performance, and Employee Attitudes: Comparing Formal and Informal Arrangements," Human Resource Management, vol. 56, no. 6, pp. 1051-1070, 2017, doi: $10.1002 / \mathrm{hrm} .21822$.

[13] E. J. Theobald, S. L. Eddy, D. Z. Grunspan, B. L. Wiggins, and A. J. Crowe, "Student perception of group dynamics predicts individual performance: Comfort and equity matter," PLOS ONE, vol. 12, no. 7, p. e0181336, Jul. 2017, doi: 10.1371/journal.pone.0181336.

[14] J. Doudová and J. Douda, "Along with intraspecific functional trait variation, individual performance is key to resolving community assembly processes," Functional Ecology, vol. 34, no. 11, pp. 2362-2374, 2020, doi: $10.1111 / 1365-2435.13646$.

[15] H. A. Manaf, S. J. Armstrong, A. Lawton, and W. S. Harvey, "Managerial Tacit Knowledge, Individual Performance, and the Moderating Role of Employee Personality," International Journal of Public Administration, vol. 41, no. 15, pp. 1258-1270, Nov. 2018, doi: 10.1080/01900692.2017.1386676.

[16] L. Poorter, C. V. Castilho, J. Schietti, R. S. Oliveira, and F. R. C. Costa, "Can traits predict individual growth performance? A test in a hyperdiverse tropical forest," New Phytologist, vol. 219, no. 1, pp. 109-121, 2018, doi: 10.1111/nph.15206.

[17] N. P. Shah, A. Parker, and C. Waldstrøm, "Examining the Overlap: Individual Performance Benefits of Multiplex Relationships," Management Communication Quarterly, vol. 31, no. 1, pp. 5-38, Feb. 2017, doi: $10.1177 / 0893318916647528$

[18] D. Carneiro and P. Novais, "Quantifying the effects of external factors on individual performance," Future Generation Computer Systems, vol. 66, pp. 171-186, Jan. 2017, doi: 10.1016/j.future.2016.05.019.

[19] R. Palma, A. Hinna, and G. Mangia, "Improvement of individual performance in the public sector: Public service motivation and user orientation as levers," Evidence-based HRM: a Global Forum for Empirical Scholarship, vol. 5, no. 3, pp. 344-360, Jan. 2017, doi: 10.1108/EBHRM-07-2017-0040.

[20] C. Gill, I. Metz, A. G. Tekleab, and I. O. Williamson, "The combined role of conscientiousness, social networks, and gender diversity in explaining individual performance in self-managed teams," Journal of Business Research, vol. 106, pp. 250-260, Jan. 2020, doi: 10.1016/j.jbusres.2018.09.003.

[21] Y. Lee and J. Y. Lee, "A multilevel analysis of individual and organizational factors that influence the relationship between career development and job-performance improvement," European Journal of Training and Development, vol. 42, no. 5/6, pp. 286-304, Jan. 2018, doi: 10.1108/EJTD-11-2017-0097.

[22] M. I. Hendri, "The mediation effect of job satisfaction and organizational commitment on the organizational learning effect of the employee performance," International Journal of Productivity and Performance Management, vol. 68, no. 7, pp. 1208-1234, Jan. 2019, doi: 10.1108/IJPPM-05-2018-0174. 
[23] N. S. Janardhanan, K. Lewis, R. K. Reger, and C. K. Stevens, "Getting to Know You: Motivating CrossUnderstanding for Improved Team and Individual Performance," Organization Science, vol. 31, no. 1, pp. 103-118, Nov. 2019, doi: 10.1287/orsc.2019.1324.

[24] G. Sharma, "Pros and cons of different sampling techniques," International journal of applied research, vol 3, no. 7, pp. 749-752, 2017

[25] M. Nisfianoor, "Modern statistical approaches to Social Sciences" (In Indonesia: "Pendekatan statististika Modern untuk Ilmu Sosial") Penerbit Salemba, 2009.

[26] I. Etikan, "Sampling and Sampling Methods," Biometrics and Biostatistics International Journal, vol. 5, no. 6, p. 00149, May 2017, doi: 10.15406/bbij.2017.05.00149.

[27] A. Pangarso, I. H. Darmawan, and I. I. Kamil, "The Effect of Compensation on the Performance of Police Hospital Employees in Bandung, Indonesia," Journal of Management and Marketing Review, vol. 3, no. 2, pp. 67-74, 2018.

[28] S. Noviaristanti, H. Mohd Hanafi, and D. Trihanondo, "Understanding Digital Industry: Proceedings of the Conferenceon Managing Google Buku," in Proceedings of the Conference on Managing Digital Industry, Technology and Entrepreneurship (CoMDITE 2019), Bandung, Indonesia, 2020, doi: 10.1201/9780367814557.

[29] M. Guglielmin, C. Muntaner, P. O'Campo, and K. Shankardass, "A scoping review of the implementation of health in all policies at the local level," Health Policy, vol. 122, no. 3, pp. 284-292, Mar. 2018, doi: 10.1016/j.healthpol.2017.12.005.

[30] C. van Weel et al., "Primary healthcare policy implementation in the Eastern Mediterranean region: Experiences of six countries," European Journal of General Practice, vol. 24, no. 1, pp. 39-44, Jan. 2018, doi: 10.1080/13814788.2017.1397624. 